\title{
MARINE ALGAL ZONATION AND SUBSTRATUM IN BEER BAY, SOUTH-EAST DEVON
}

\author{
By G. T. BOALCH \\ Department of Botany, University College, London
}

(Text-figs. I-4)

A preliminary examination of the marine algal zonation of Beer Bay, southeast Devon, indicated that there might be some divergences from the basic zonation on the south coast of England as described by Grubb (1936) and Evans (1947). Moreover, it appeared that the divergences might be due to an effect of the substratum being superimposed upon the normal intertidal zonation. To investigate this further a survey of the marine algal vegetation and the substratum of the intertidal regions of Beer Bay was carried out.

Beer is situated approximately at the centre of Lyme Bay (National Grid 30/2389). The Bay is shown in detail in Fig. I, with the areas surveyed stippled. The Bay is exposed from the south-east to the south. Although the southeast gales can be severe at Beer, they are less frequent than gales from the south-west, which seem to produce the most severe wave-action in the Bay. In these gales, the waves, which are travelling in a north-easterly direction outside the headland, seem to alter their direction, and travelling due north, sweep right into the Bay and cause considerable wave-action, even along the cliffs on the west side. The exposed nature of the Bay is reflected in the absence of Pelvetia canaliculata Dcne. \& Thur. and Ascophyllum nodosum Le Jol., the almost complete absence of Fucus spiralis L., and the occurrence of Alaria esculenta Grev. at Beer Head and The Hall (Fig. I).

Throughout this survey the marine algae were identified from the Handbook of the British Seaweeds (Newton, I93I), and the names used are those given in Parke's (1953) Check List.

\section{SUBSTRATUM}

The most westerly outcrop of the Chalk on the south coast of England occurs at Beer, and as a result the cliffs have been described by several authors (Meyer, I874; Rowe \& Sherborne, I903; Jukes-Browne, 1904). The cliffs surrounding the Bay consist almost entirely of the Upper, Middle and Lower Chalks, but there is a zone of $2 \cdot 5-3 \mathrm{~m}$ at the base of the cliffs where the chalk passes into the Upper Greensand. Directly beneath the clearly defined Lower Chalk there is a I m bed of harder rock, which Rowe \& Sherborne (I903) 
described as a transition bed between the Lower Chalk and Upper Greensand. They called this the Cenomanian Limestone. Jukes-Browne (I904), Dewey (I948), and Woodward \& Ussher (I9II) all include this bed in the Lower Chalk and apply the term Cenomanian to all the Lower Chalk at Beer. Below this zone occurs the siliceous rock shown as the Upper Greensand and it is the harder parts of this Greensand that form most of the flat expanse of rock which is exposed on each side of the Bay at low tide. However, in a few places, particularly on the east side of the Bay, the Cenomanian Limestone persists on top of the Greensand and takes the form of large flat-topped rocks

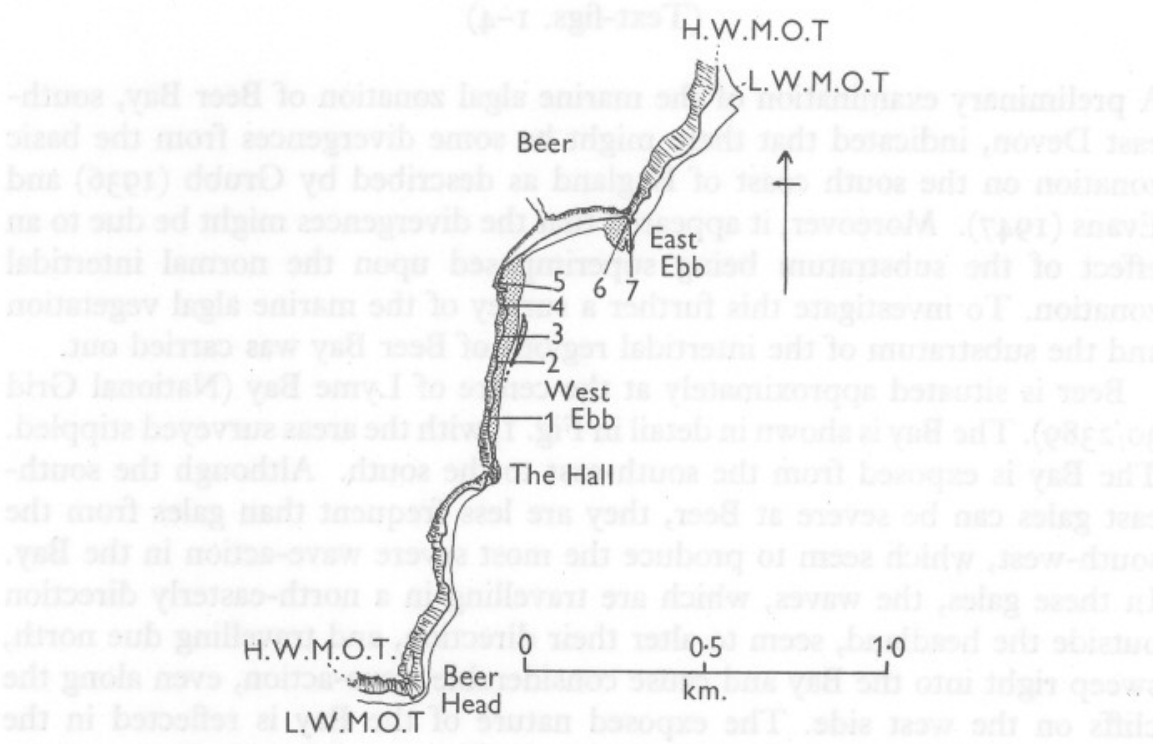

Fig. I. Map of Beer Bay. Areas which were investigated are stippled.

Numbered lines indicate positions of transects.

projecting well above the general level of the surrounding Greensand. At the base of the cliffs there are areas of chalk boulders which are the remains of extensive falls of cliff. Although these are much softer than fragments of the Greensand or of the Limestone, and tend to be eroded away rather quickly, they are continually being replaced by minor cliff falls. The beach is entirely of pebbles which range in size from stones $10-15 \mathrm{~cm}$ in diameter down to a fine shingle. Pebbles also occur in small isolated areas along the foot of the western cliffs where there are no chalk boulders. In the centre of the Bay and below the lowest tides there is a rather coarse sand. 


\section{Plane-table maps}

\section{METHODS OF SURVEY}

Plane-table maps of the two sides of the Bay were prepared on a scale of $30 \mathrm{ft}$. to I in. and various fixed points marked on them to facilitate later work. The rock outcrops on both sides of the Bay were only mapped down as far as extreme low-water spring tides. In August of both I954 and I955 the substratum and the zones of the dominant algae were plotted on these maps and they are reproduced on a reduced scale as Figs. 2 and 3.

\section{Transects}

In 1955, seven transects, down through the intertidal zone, were investigated. The positions of these transects are shown on Fig. I. Levelling along these transects was done with a modified form of the levelling apparatus developed by Miss J. M. Kain (in preparation). On a calm day the height of the sea in relation to fixed points on the transects was recorded and with the aid of a tidal curve and the predicted range of the tide for that day, which were kindly supplied by the Hydrographer to the Admiralty, the mean tidal levels, as quoted by the Admiralty, were found for each transect. This was later checked by levelling back to a bench mark.

\section{Substratum maps}

\section{RESULTS OF THE SURVEY}

Greensand, limestone, chalk boulders and pebbles are plotted on the substratum maps, and the areas colonized by the reef-building worm Sabellaria alveolata are also indicated. These worms build up extensive colonies of honeycomb-like structure at certain points between high-water neap tides and low-water spring tides. The colonies are usually quite extensive and vary considerably in depth. In some places they form a uniform cover $2-5 \mathrm{~cm}$ deep and in other places they are in the form of tussocks. As will be shown later it is mainly on these colonies that the anomalies in the normal zonation occur.

\section{Species maps}

Five main groups are considered in the species maps, these are: Enteromorpha spp., Ulva lactuca, Fucus vesiculosus, F. serratus and Gigartina stellata. Enteromorpha was not divided up into species, but it was known to include Enteromorpha intestinalis and E. compressa and probably several other species. The Fucus vesiculosus was a form without vesicles and was probably the form described in Newton (I93I) as F. vesiculosus var. evesiculosus Cotton. Throughout the area this was the only form of $F$. vesiculosus found, and Knight \& Parke (I950) say: 'An almost complete absence of vesicles characterizes the whole $F$. vesiculosus zone on the Devon, Manx and Argyll coast, in very 
exposed places such as at the foot of vertical cliffs exposed to full surf action.' At Beer this alga is not growing on vertical cliffs but, as already mentioned, there is considerable wave action in the Bay. Laminaria spp. were not plotted as these only became dominant below the level of the mapped areas. It should be recorded that, although in several places the high-tide mark was well up the cliffs, there were none of the zones described by Anand (1937) as being characteristic of the chalk cliffs of Sussex.

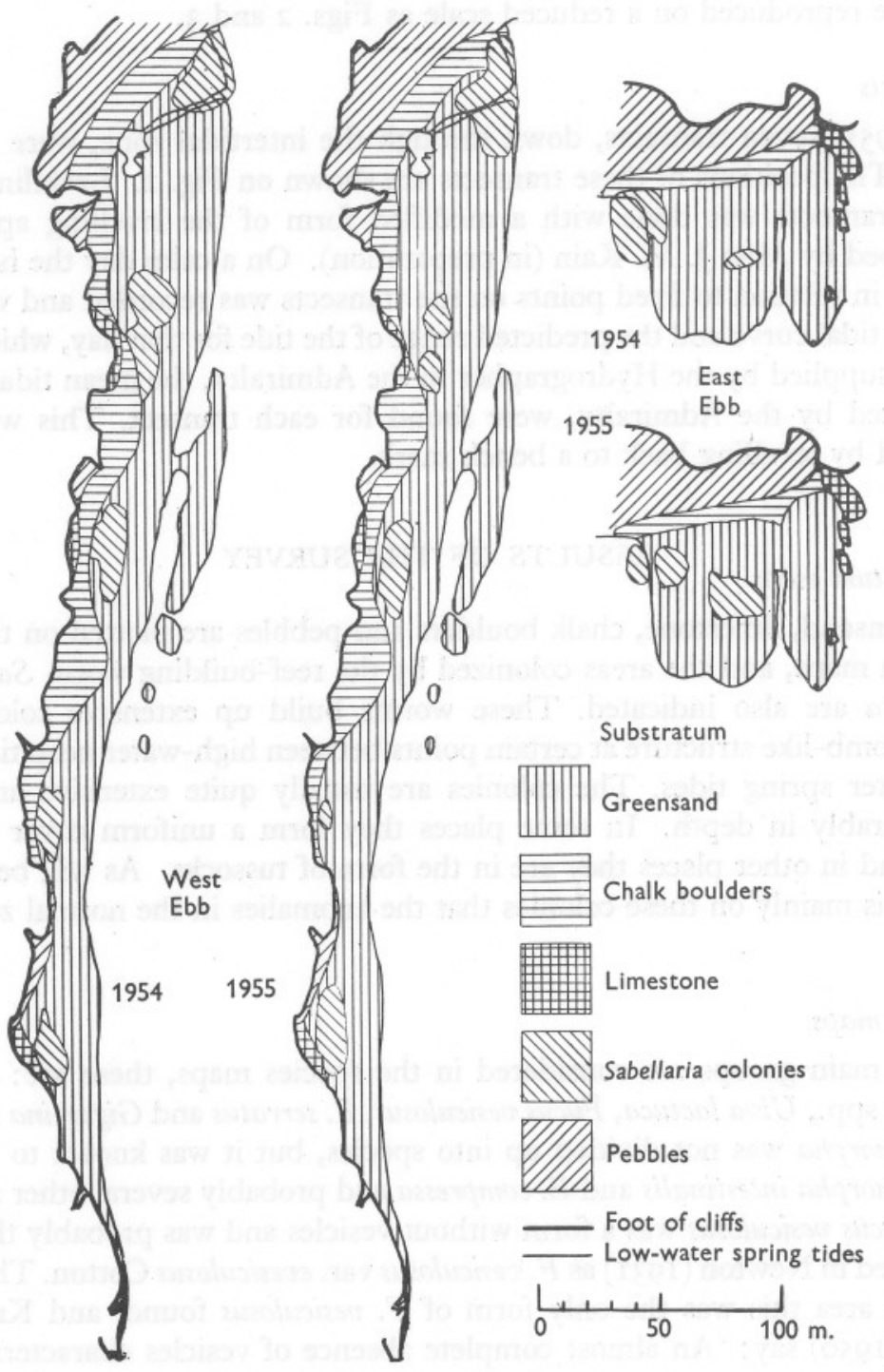

Fig. 2. Substratum maps 1954 and 1955. 


\section{Species and substratum}

The maps of the west side of the Bay show five areas colonized by the Sabellaria worms and the major parts of these colonies were dominated by Ulva lactuca or Gigartina stellata. On the east side of the Bay the worm colonies were also dominated by either Ulva or Gigartina. It should, however, be pointed out that Gigartina was also dominant on some extensive areas that

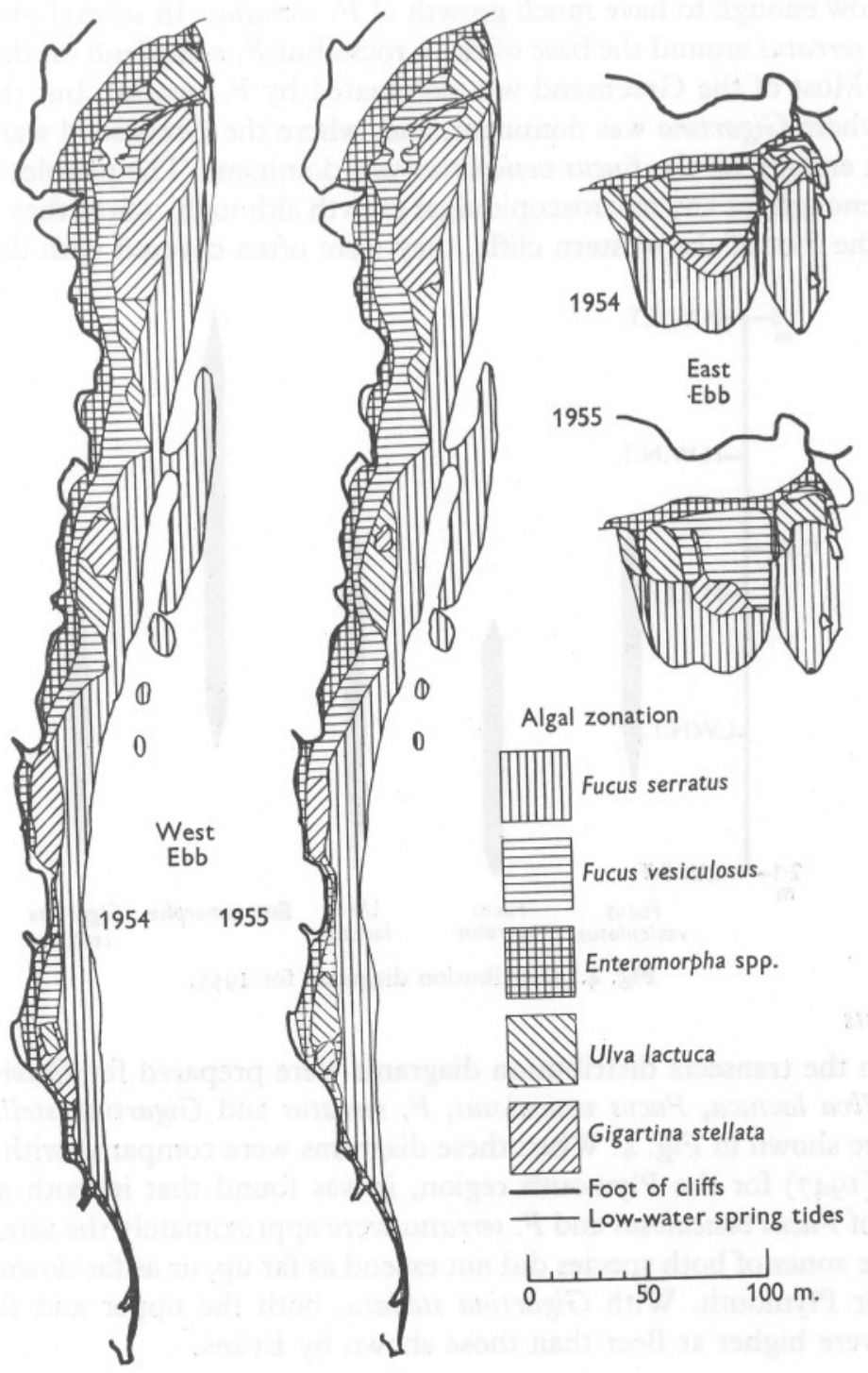

Fig. 3. Algal zonation 1954 and 1955 . 
were not colonized by the Sabellaria worms but, apart from one or two very small areas, Ulva was only dominant on areas colonized by the Sabellaria worms. The chalk boulders at the base of the cliffs were almost entirely covered with a dense growth of Enteromorpha. This growth was correlated with the occurrence of fresh water running out of the Greensand at the base of the cliffs and forming streamlets running between these chalk rocks. Fucus vesiculosus dominated most of the rest of the chalk rocks which did not extend down low enough to have much growth of $F$. serratus. In several places there was $F$. serratus around the base of these rocks but $F$. vesiculosus on the top and sides. Most of the Greensand was dominated by F. serratus, but there were areas where Gigartina was dominant, and, where the Greensand was exposed at high enough levels, Fucus vesiculosus was dominant. The pebbles were not stable enough for any macroscopic algal growth although, where they occurred along the foot of the western cliffs, they were often covered with diatoms.

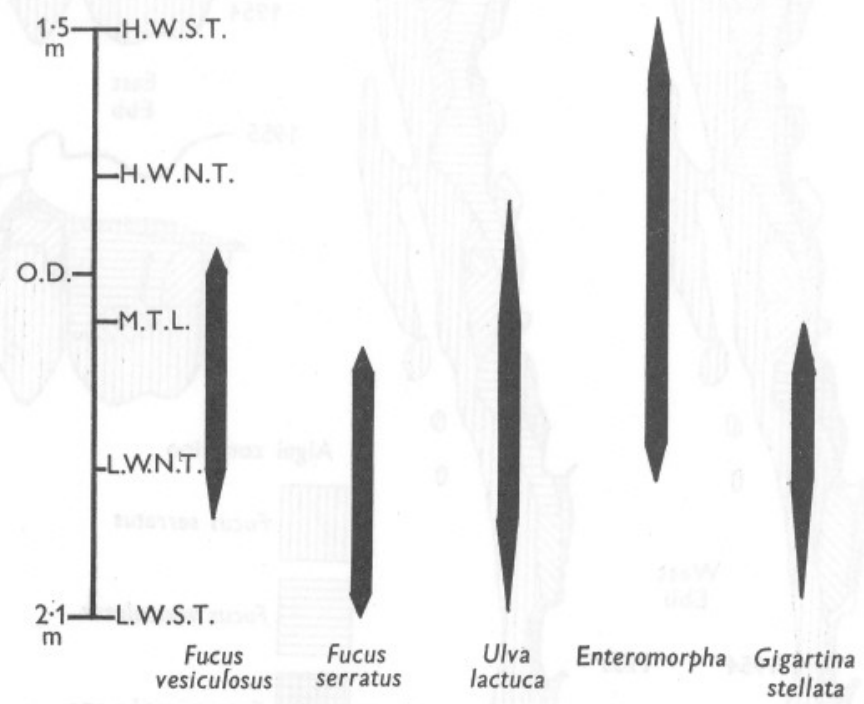

\section{Transects}

Fig. 4. Distribution diagrams for 1955 .

From the transects distribution diagrams were prepared for Enteromorpha spp., Ulva lactuca, Fucus vesiculosus, F. serratus and Gigartina stellata, and these are shown in Fig. 4. When these diagrams were compared with those of Evans (1947) for the Plymouth region, it was found that in both areas the means of Fucus vesiculosus and F. serratus were approximately the same, but at Beer the zones of both species did not extend as far up, or as far down, as they did near Plymouth. With Gigartina stellata, both the upper and the lower limits were higher at Beer than those shown by Evans. 


\section{NITROGEN ESTIMATIONS ON ULVA}

In an attempt to determine if the dominance of Ulva lactuca on the Sabellaria colonies was in any way reflected in a change in the nitrogen-content of the Ulva, some estimations of the total nitrogen-content of Ulva samples were carried out. The material was collected at Beer in June 1956 and the samples were treated immediately on return to London. Ulva was collected from areas of $100 \mathrm{~cm}^{2}$ and, after a quick washing to remove sand, etc., was dried to constant weight in an oven at $100^{\circ} \mathrm{C}$. The percentage nitrogen content of the samples, on a total dry-weight basis, was then determined by means of the micro-Kjeldahl method. Eight samples of Ulva growing on Sabellaria colonies, and two samples not on colonies, were estimated. The mean of the dry weights of Ulva per $100 \mathrm{~cm}^{2}$ on the colonies was $1.37 \mathrm{~g}$, and off the colonies was $\mathrm{I} \cdot$ OI $\mathrm{g}$. The mean percentage nitrogen on a total dry-weight basis was $0.68 \%$ on the colonies, standard deviation 0.21 , and off the colonies was $2.64 \%$, standard deviation 0.14 . These results show a slightly higher yield per unit area, but a lower nitrogen content per unit dry weight on the colonies. This may indicate a more rapid growth of Ulva on the colonies. In both cases the values are considerably less than those quoted by Milner (1953), who gives a value of $4.87 \%$ on a dry-weight-less-ash basis, i.e. $3.95 \%$ on a total dry-weight basis.

\section{DISCUSSION}

It seems clear from the species maps that, at Beer, Ulva lactuca dominates large areas only if they are colonized by the Sabellaria alveolata worms. On the Sabellaria colonies the Ulva is different in appearance from that off the colonies, in that the plants on the colonies are smaller in height and much more tufted at the base than the forms growing off the colonies. This dominance of Ulva lactuca on the colonies of Sabellaria may be related to one or more of three possibilities. (i) The Sabellaria colonies form a very unstable substratum and the larger algae such as the fucoids cannot become established on them. (ii) Due to the presence of some factor produced by the Sabellaria worms, the growth of Ulva on the colonies is very rapid and hence the Ulva soon forms a complete cover to the exclusion of other algae. (iii) The colonies produce something that is toxic to most algae but not to Ulva.

The first factor does not seem to be likely as Gigartina plants reach considerable size where they are the dominant plants on the Sabellaria colonies and these probably grow at a comparable rate to the fucoids. Further, in some areas the fucoids do encroach slightly on to the Sabellaria colonies and are thus able to grow on the colonies if they get a chance. By the same reasoning, the idea that there may be some toxin released must be excluded. It is, however, difficult to show any definite evidence for the second factor and the nitrogen estimations did not give any explanation here.

Cotton (19I0) noted the good growth of Ulva in quiet brackish water that 
was strongly polluted, he also found that Ulva could assimilate high levels of nitrate and ammonia. Arber (I90I) asserted that abnormally high levels of nitrates caused inhibition of carbon-assimilation in Ulva cultures. Letts \& Richards (I9II) found the addition of filtered sewage, up to ro \%, gave a considerable increase in growth, growth being estimated by the increase in surface area. They also found that the increase was greater than that brought about by the addition of nitrate and phosphate. Foster (I9I4) found that Ulva grew quite well on ammonium nitrate, urea and acetamide. In all this work no attempts were made to prevent, or even reduce, bacterial contamination.

Kylin (1942) found that glucose, ascorbic acid and heteroauxin, at certain concentrations, all increased the rate of division in Ulva sporelings. In I943 he commented on the stimulatory effects of thiamin and of biologically active substances in the surface layers of the sea, especially if the water was collected in regions of dense algal growth. Later (1945) he found that the effects of these biologically active substances and the effects of iron and manganese were additive. Again, however, these cultures were contaminated.

Cotton (I9II) commented on the abundance of Ulva on mussel beds and pointed out that, under these conditions, sporing tends to be reduced and the main form of reproduction is vegetative. As previously stated, I have noted that the plants on the Sabellaria colonies at Beer are small in extent and very tufted at the base. This may indicate the extensive vegetative reproduction mentioned by Cotton.

Gigartina occurs both on the Greensand and on the Sabellaria colonies and thus appears not to be in any way affected by the Sabellaria worms, although it should be pointed out that the highest level at which Gigartina occurred at Beer was on a Sabellaria colony. As was previously stated, the two species of Fucus do not show any divergences from the normal zonation found on the south coast of England. Both species occur on all types of substratum.

Enteromorpha shows a wide distribution throughout the intertidal zone, but, as this genus is known to be greatly influenced by local conditions such as the presence of fresh water and high nitrogen sources, the wide distribution is not surprising. Although Enteromorpha was very abundant on the chalk boulders, it occurred also at the same levels on the Greensand, and, furthermore, its distribution was correlated with that of fresh water which ran from the base of the cliffs, and thus, in this case, there was no correlation of distribution with substratum.

From this investigation it is concluded that the distribution of the main marine algal species in Beer Bay was quite normal for an exposed area on the south coast of England and, with the exception that Ulva lactuca was only dominant over large areas where these were colonized by the reef-building worm Sabellaria alveolata, there was no effect of substratum on the distribution of the algal species. 
I wish to thank Dr G. E. Fogg for his helpful criticism of this work, Mr J. H. Belcher for help with the nitrogen estimations, and Miss J. M. Kain for help in the construction of the level used on the transects.

\section{SUMMARY}

The intertidal zonation of the dominant algal species in Beer Bay, south-east Devon, was examined in relation to substratum by means of plane-table maps and transects. The dominance of Ulva lactuca on colonies of the reef-building worms Sabellaria alveolata was noted, but the distributions of Fucus vesiculosus, F. serratus, Gigartina stellata and Enteromorpha spp. showed no correlation with substratum.

\section{REFERENCES}

ANAND, P. L., 1937. An ecological study of the Algae of British Chalk cliffs. F. Ecol., Vol. 25 , pp. 153-88, 344-67.

ARBER, E. A. N., I90I. On the effect of nitrates on the carbon assimilation of marine Algae. Ann. Bot., Lond., Vol. 15, pp. 669-8I.

Cotton, A. D., I9I0. On the growth of Ulva latissima $\mathrm{L}$. in water polluted by sewage. Kew Bull., I9ro, pp. I5-19.

- I9ri. The ecology of Ulva. 7th Rep. Royal Commission on Sewage Disposal. Appendix 3, pp. I2I-43.

Dewey, H., 1948. British Regional Geology South West England. D.S.I.R. Geological Survey.

Evans, R. G., I947. The intertidal ecology of selected localities in the Plymouth neighbourhood.s F. mar. biol. Ass. U.K., Vol. 27, pp. 173-218.

FosTER, G. L., I9I4. Indications regarding the source of combined nitrogen of Ulva lactuca. Ann. Mo. bot. Gdn, Vol. I, pp. 229-35.

GruBB, V. M., 1936. Marine algal ecology and the exposure factor at Peveril Point, Dorset. F. Ecol., Vol. 24, pp. 392-423.

Jukes-Browne, A. J., I904. The cretaceous rocks of Britain, Vols. I and 2. Mem. geol. Surv. U.K.

Knight, M. \& Parke, M., I950. A biological study of Fucus vesiculosus L. and F. serratus L. F. mar. biol. Ass. U.K., Vol. 29, pp. 439-5I4.

KylIN, H., I942. Über den Einfluss von Glucose, Ascorbinsäure und Heteroauxin auf de Keimlinge von Ulva und Enteromorpha. K. fysiogr. Sällsk. Lund Förh., Bd. I2, pp. I-I4.

- 1943. Über die Ernährung von Ulva lactuca. K. fysiogr. Sällsk. Lund Förh., Bd. I3, pp. I-13.

- 1945. Weitere Angaben über die Ernährung von Ulva lactuca. K. fysiogr. Sällsk. Lund Förh., Bd. 15, pp. I-5.

LetTS, E. A. \& RicharDs, E. H., I9II. On green sea-weeds in relation to the pollution of the waters in which they occur. 7 th Rep. Royal Commission on Sewage Disposal, Appendix 3, pp. 72-I20.

MeYER, C. J. A., I874. The Cretaceous rocks of Beer Head. Quart. F. geol. Soc. Lond., Vol. 30, pp. 369-93.

MILNER, H. W., I953. The chemical composition of Algae. Algal culture from laboratory to pilot plant. Publ. Carneg. Instn, No. 600, pp. 285-302. 
Newton, L., I931. A Handbook of the British Seaweeds. London: British Museum (Natural History).

PARKE, M. W., I953. A preliminary check-list of British marine Algae. F. mar. biol. Ass. U.K., Vol. 32, pp. 497-520.

Rowe, A. W. \& SHERBorNe, C. D., I903. The zones of the White Chalk of the English Coast. III. Devon. Proc. Geol. Ass., Lond., Vol. I8, pp. I-5I.

WoodWARD, H. B. \& UsSHER, W. A. E., IgII. Geology of the country near Sidmouth and Lyme Regis. Geological Memoir, No. 326, and No. 340. 